\title{
13 COVID-19 and first wave response in Kenya
}

\author{
Rose B. Osoro
}

\subsection{Introduction}

The COVID-19 pandemic and its containment measures have had tragic impacts on both peoples' lives and their livelihoods, its far-reaching consequences have indelibly disrupted Kenya's economy and businesses. At the beginning of the year, the Kenya National Treasury (NT) had projected the country's economy to grow by 6.1 percent and 7.0 percent for 2020 and 2021 financial years. However, because of the economic impact of COVID-19, these figures have been revised downwards to 2.6 percent and 5.3 percent, respectively. As the situation in Kenya moves with the slow opening of the economy due to the continued indeterminable presence of the corona virus, the NT revised growth rates may just be but wishful thinking.

As of the 2019 Kenya's population and housing census, the country's population stands at 47.5 million consisting of 23.5 million and 24.0 million males and females, respectively, and is mainly composed of youthful populace with 12.1 million households (Kenyan National Bureau of Statistics 2019). Any intervention to mitigate the effects of the pandemic hence must be looked at through the lens of gender equity and youth as the COVID-19 confirmed cases have statistically disproportionately affected males and the youth. As of 27 July 2020, Kenya had registered a total of 17,975 confirmed cases with 285 deaths giving a case fatality rate of 1.6 percent. Of the 17,975 cases, 11,765 (65 percent) were recorded as males and 6,210 (35 percent) as females. Most of the cases, 5,855 (33 percent), were identified in the age group of 30-39 years. Of the total cases, 285 deaths were reported with 213 (75 percent) being males and 72 (25 percent) as females.

The statistics above invalidate previous notions and myths about COVID-19 in Kenya that the virus only affected the elderly; or that it was a "rich man's disease," and the claim that Africans may have a natural immunity against the disease (Table 13.1).

Table 13.1 Key Statistics on COVID-19 in Kenya as of 10 January 2021

\begin{tabular}{lllll}
\hline $\begin{array}{l}\text { Cumulative } \\
\text { Cases }\end{array}$ & $\begin{array}{l}\text { Cumulative Cases per } \\
\text { 100,000 Population }\end{array}$ & $\begin{array}{l}\text { Cumulative } \\
\text { Deaths }\end{array}$ & $\begin{array}{l}\text { Cumulative Deaths per } \\
100,000 \text { Population }\end{array}$ & $\begin{array}{l}\text { Case Fatality } \\
\text { Percentage }\end{array}$ \\
\hline 98,184 & 182.6 & 1,704 & 3.2 & 1.7
\end{tabular}

Source: World Health Organization Weekly epidemiological update - 12 January 2021. Geneva: WHO, 2021. Available from https://www.who.int/publications/m/item/weekly-epidemiological-update 


\subsection{Kenya's constitutional framework}

Kenya ushered in a new political and economic governance system with the promulgation of a new constitution in 2010. The Constitution introduced a bicameral legislative house, devolved system of government, a constitutionally tenured judiciary, and an independent electoral body among other broad and sweeping changes. The first election under the new constitution was held in 2013. Devolution now in its second term is meant to continue to address governance, economic and development glitches arising from the former 'unitary' system that was viewed as highly centralized, undemocratic, and inequitable. Decentralization, known as "Ugatuzi," remains the centerpiece of reform in Kenya and the most transformative aspect of the country's new constitution. Article 6 of the Constitution provides that the territory of Kenya is divided into the counties and that the governments at the national and county levels are distinct and interdependent and shall conduct their mutual relations on the basis of consultation and cooperation. Each level of government has delimited assignments on expenditures, revenues, and service delivery. The fourth schedule of the Constitution assigns 35 functions to the national government and 14 service delivery functions to the County governments. Constitutionally, functions relating to policy formulation, setting of standards and norms, and any residual functions not fall under the functional jurisdiction of the national government. In order to implement the delimited functions, the two levels of government have been under Article 209 mandated with imposition powers to raise revenues within their jurisdiction (Constitution of Kenya 2010).

Kenya's County governments are relatively autonomous and are represented at the national legislature by the Senate. The Senate's role is to represent and serve to protect the interests of the counties and their governments and to participate in all matters concerning counties; determine the allocation of national revenue among the counties and exercise oversight over national revenues allocated to the counties (Kangu 2015). There are 47 counties forming the territory of Kenya; christened " 48 Governments, 1 Nation." The Judiciary and independent tribunals are shared functions.

The functions and provision of services of county governments have further been decentralized to the urban areas and cities within the counties (Kenya, G.o. 2012a). There is an existing legal framework that provides for the classification, governance, and management of urban areas and cities. It has been noted that Kenya is still at an early stage of urbanization, but by 2050 , about half of the population are expected to be living in cities. Around 27 percent of Kenyans currently live in urban areas. The country is urbanizing at rate of about 4.3 percent per a year. That leaves 73 percent of the population still living in rural areas (World Bank 2015).

\subsection{Transfer of functions and Nairobi city county as a decentralized unit}

The Country's capital city Nairobi is classified as county number 47. Tensions have arisen with undertones that Nairobi City County ought to be under the jurisdiction of the national government due to the strategic position as the capital city. Recently, the governor under "duress," as he claimed later, signed off transfer of major functions to the national government. The Nairobi county government previously riddled with allegations of corruption and inefficiency has now been left with skeleton functions. 
A new body, Nairobi Management Service (NMS) has taken over the running of the capital, and the leader has been given a seat in Cabinet at the national government executive. It is important to note that the national government's role and intervention in the counties' affairs are constitutionally constrained. The constitution dictates that while a function can be transferred from one level of government to the other for clear reasons, the constitutional responsibility for the performance of the functions shall remain with the government to which the functions are assigned by the constitution.

\subsection{COVID-19 in Kenya}

Africa reported its millionth COVID-19 case early August. It seems that the continent has weathered the pandemic relatively well with less than one confirmed case for every thousand people and 23,000 deaths (Nordling 2020).

Table 13.2 below shows continental confirmed cases of COVID-19 compared to Kenya as follows:

In comparison with world statistics, it was evident in the first wave; the virus had spared the continent of Africa.

In a country of over 40 million people, Kenya has also exceeded expectations. The Country had recorded 743 deaths as of the end of September compared to expert estimates of ominous figures (Ministry of Health Press Release 2020). Following a peak in July, the caseload rapidly abated. Kenyan epidemiologists predict a "long-tailed decline," meaning that the virus is here for the long run.

\subsubsection{Emergency and intergovernmental structural interventions response to COVID-19}

On 13 March 2020, just a day after the first case of COVID-19 was confirmed in the Country, the government gave directives that have been implemented through policy measures and behavioral protocols aimed at containing the spread of COVID-19. These directives were effected through a special gazette notice by the Cabinet Secretary in charge of health on 6 April 2020. The measures include suspension of learning in all educational institutions; social distancing through minimizing congestion in public transport, shopping malls, entertainment venues, and social gatherings; self-or compulsory quarantine; strict evaluation and monitoring protocol designed to proactively seek out and test persons who may have been exposed; daily nationwide curfew from 11 PM to 4 AM; and Cessation of movement in and out of Nairobi Metropolitan Area. These measures being emergency response were decided and coordinated by the national government with minimal input from the county governments.

Table 13.2 Total Number of Cases, Recoveries, and Deaths in Kenya and in Africa

\begin{tabular}{llll}
\hline Cases & Africa & Kenya & $\%$ Share \\
\hline Confirmed cases & $1,632,634$ & 44,196 & 2.7 \\
Recoveries & $1,343,479$ & 31,725 & 2.3 \\
Deaths & 39,357 & 825 & 2.1 \\
\hline
\end{tabular}

Source: WHO, 16 October 2020 
It is believed that support and compliance of county governments of the measures undertaken prevented widespread infections and averted the misery feared by specialist health leaders. The system, as fragile as it is, has not broken yet (Fielder 2020). That notwithstanding, other groups (Law society of Kenya, religious groups, and business-people) regarded the measures as punitive even to an extent of seeking judicial intervention to block execution.

One of the intergovernmental structural measures put in place to respond and cushion Kenyans from the adverse effects of the pandemic was the establishment of a National Coordination Committee on the Response to the Corona Virus Pandemic (NCCRCP). The committee, chaired by the Cabinet Secretary for the Ministry of Interior and Coordination of National Government with its several working groups including the National Economic and Business Response (NEBR), had the responsibility of availing information to facilitate formulation of appropriate strategies for intervention on socio-economic effects of the disease. The Committee's membership included Cabinet Secretaries in charge of Health, National Treasury, Foreign Affairs, Information and Communication Technology, Public Service, Defense, Agriculture, Attorney-General, Head of Public Service, the Council of Governors (CoG) chairperson, Principal secretary in charge of Interior, Chief of Staff Office of President, Chief of Defense Forces, Director-General National Intelligence Service, and Deputy Chief of Staff for Policy and Strategy.

Through its structure and composition, the NCCRCP was being spearheaded by the national government with a majority in membership with an assumption that County governments were adequately consulted and represented by including the CoG's chairperson to the committee. There has not been any overt complaint of under-representation or lack of consultation of county governments although many decisions of this committee were directly communicated by the national government.

The NCCRCP was established to provide a coherent national framework to respond to the pandemic, provide leadership, and policy guidance on the overall response to the pandemic among other functions. It has been the main coordinating agency on COVID-19 and has had support structures and coordination mechanisms in form of working groups namely:

- National Emergency Response;

- National Economic and Business Response;

- County Coordination and Food Security Committee;

- National Security Preparedness and Response Working Groups.

The NCCRCP together with its various working groups have jointly been able to improve coordination of reporting from the county level, provide daily media briefings, and impact assessment of public health interventions, train 91,557 health Care workers, sensitize 64,000 community health volunteers, validate 38 laboratories from an initial two, enhance resource mobilization, develop interim human resources for health protocols, and recruitment of additional staff for COVID-19 response.

In our view, the pandemic has strengthened the intergovernmental relations between the two levels of government in a cross-sectoral manner. For instance, the statutory intergovernmental apex body, the National and County Governments Coordinating Summit, comprising the president and the 47 governors has convened three Extra-Ordinary Sessions within six months of the pandemic unlike a once-a-year 
session previously. The first session was convened on 10 June 2020 by the president with all the governors to: Review effectiveness of the containment measure; Commit county governments to deliver isolation facilities with at least 300-bed capacity; and develop protocols for progressive reopening of the economy.

\subsubsection{Managing the COVID-19 crisis - fiscal measures}

The government has made a raft of fiscal measures to cushion citizens and businesses from the adverse effects of COVID-19 pandemic. This is through the implementation of a range of fiscal measures in the context of the Finance Act 2020. The fiscal measures were announced by the President on 25 March 2020 and later tabled in Parliament through the Finance Bill on 6 May 2020 for debate and approval. Most members for the first time attended the proceedings virtually in compliance with COVID-19 rules and regulations. It is worth noting that county governments did not introduce any new legislation on the revenue raising powers as a response to COVID-19.

The fiscal measures contained in the Finance Act 2020 were targeted to provide in the medium term the much-needed relief to the economy and necessitate additional disposable income to the people and businesses. These measures included: 100 percent Tax Relief for low-income earners; Reduction of both Income Tax Rate and Corporation Tax from 30 percent to 25 percent; Reduction of the turnover tax rate from the current 3 percent to 1 percent for all Micro, Small, and Medium Enterprises (MSMEs), and Appropriation of an additional cash transfer allocation to the elderly, orphans, and other vulnerable members of the society. The paradox of the government's tax relief measures is that some sectors of the economy have not been able to directly benefit as aspired.

The government further initiated an eight-Point Economic Stimulus Programme (ESP) which is currently under implementation in all the 47 counties (National Treasury 2020b). The eight-Point ESP is intended to stimulate growth and cushion families and companies during the COVID-19 pandemic. They include allocating additional resources to:

1 Hire local labor for rehabilitation of access roads and footbridges to alleviate the effect on the youth;

2 Ministry of Education to hire 10,000 teachers and 1,000 Information and Communication Technology interns to support digital learning and acquisition of 250,000 fabricated desks in preparation for reopening of learning institutions;

3 Fast track payment of outstanding VAT refunds and other pending payments to SMEs and provide seed capital for SME Credit Guarantee Scheme;

4 Hire additional 5,000 healthcare workers and expand bed capacity in public hospitals;

5 Supply of firm inputs through e-vouchers, targeting 200,000 small-scale farmers to alleviate food security and assist flower and horticultural producers to access international markets;

6 Soft loans to hotels and related establishments through Tourism Finance Corporation (TFC) and to engage 5,500 community scouts and to preserve $160 \mathrm{commu}-$ nity conservancies;

7 Rehabilitate wells, water pans, and underground tanks in the Arid \& Semi-Arid Areas. Additional allocation for flood control measures; 
8 Enforce the "Buy Kenya Build Kenya" Policy through an allocation to purchase locally manufactured vehicles.

While the actual number of beneficiaries of the above interventions cannot be ascertained, there is optimism among citizens that something is actually being done.

\subsubsection{Social economic impact of COVID-19}

One of the notable outputs from the NCCRCP was the commissioning of a survey that was conducted by the National Bureau of Statistics (KNBS) to provide information on the effects of COVID-19 on interactions between social and economic factors. Interestingly, the survey showed a somewhat rosy picture of the state of the economic status of the citizens. Nationally, 78.1 percent of households reported to be food secure about 77.6 percent of the households reported having no challenges in accessing market/grocery store to purchase food items (Statistics 2020b). In normal circumstances, abundance of food means reduced prices. However, this was not the case. The survey found out that about four out of five $(78.8$ percent) of the households indicated having experienced an increase in food prices attributable to COVID-19 pandemic. Moreover, the fall in world oil prices and favorable weather conditions have contributed to the stability.

On the flipside, 59.2 percent of the respondents reported a change in their cost of travel due to the pandemic. Further, we observed that 14.4 percent of the respondents changed their main means of transport out of which 62.2 percent opted to walk while 19.4 percent opted to use "Boda Boda" (motorcycle taxis). There have been at least $1,716,706$ job losses among the working population aged between 16 and 64 years between April and June 2020. The unemployment rate increased to 10.4 percent in the second quarter of 2020 compared to 5.2 percent recorded in the first quarter of 2020 (Statistics KNBS 2020a).

\subsubsection{Regional collaboration}

While there have been elaborate steps taken by the government to contain the spread of the virus, some of the initiatives taken have threatened to derail regional trade. Stringent measures adopted by Kenya do not tally with those of the neighbors leading to retaliatory actions. Regional trade has been paralyzed. The stand-off escalated when the Kenyan government announced the closure of its borders affecting negatively on regional trade. The borders are slowly opening up but possession of COVID-19 Free Certificate is still a requirement irrespective of the cost implications.

\subsubsection{Easing of the measures and a threat of the second wave}

As we write this toward the end of October 2020, some of the government measures have been lifted with partial reopening of learning institutions being the greatest leap. Interestingly, there is an unsettling trend emerging in the last week of October. There is an increase in the number of new infections eliciting feelings of a second wave. Hospitals have announced full capacity, and the field hospitals that had been established and not used before are being reopened. This is a worrying trend, and both levels of governments are on high alert (Figure 13.1). 


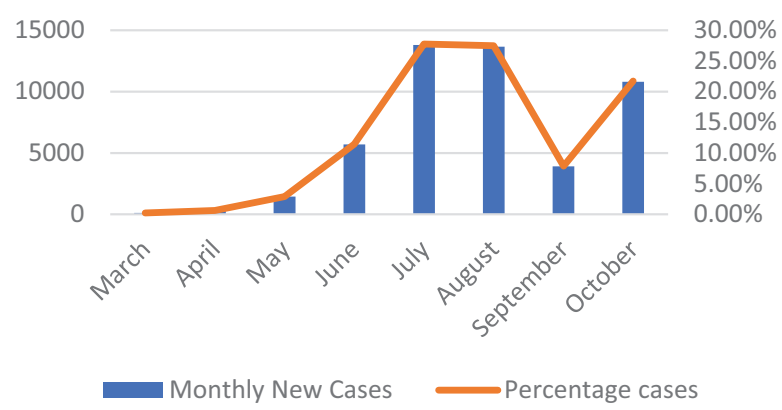

Figure 13.1 Monthly COVID-19 Cases from March until October 2020 in Kenya Source: Cumulated weekly WHO numbers.

\subsection{COVID-19 and devolution in Kenya}

\subsubsection{Coordination challenges and successes during the pandemic}

As highlighted earlier, Kenya is a devolved state with two distinct and interdependent levels of government - national and county - that are required to conduct their mutual relations in a consultative and cooperative manner. The Constitution equally provides for a system of intergovernmental relations, including dispute resolution between and among the governments.

Other than 'The Summit,' legislation further provides for sectoral working groups and Committees to enable consultations between the national government line ministries and the county departments (Kenya, G.o. 2020c). Horizontal coordination, the Constitution provides for cooperation and relations amongst the 47 counties hence creating the CoG to provide a platform for consultations and sharing of information among the county governments (Kenya, G.o. 2020c). For instance, on vertical fiscal relations, the national Public Finance Management Act establishes the Intergovernmental Budget and Economic Council to provide a forum for intergovernmental consultations on financial matters (Kenya, G.o. 2012b). Despite the presence of an elaborate intergovernmental framework, during the pandemic, the system had largely been unresponsive, prompting re-emergence of other avenues of engagement such as NCCRP.

Health is a devolved function. There are however particulars of the function that are concurrent in nature as the two levels of governments have shared jurisdiction, collaboration, and joint tasks. The effective implementation of the health functions squarely therefore lies in the mutual collaborative and cooperative approach by the two levels of government. The national government is constitutionally allowed to legislate on health policy and national referral health facilities while counties are restricted to legislating in respect of county health facilities and pharmacies; ambulance services; promotion of primary health care; licensing and control of undertakings that sale food to the public; veterinary services excluding regulation of the profession. The public health system in Kenya is characterized by 0.04 doctors; 0.1 nurses and midwives; 0.8 beds per 1,000 inhabitants. The emergence of COVID-19 and the eminent spread has therefore decorously caused trepidation in both levels of government. 


\subsubsection{County government initiatives and coordination}

The CoG on its own has equally held nine sittings and convened a virtual COVID-19 Conference, eight governors representing the CoG have through the intergovernmental processes been co-opted into committees of the NCCRCP just for the purposes of coordinating mitigating efforts toward COVID-19. The CoG through its leadership embraced the newly established intergovernmental structures established.

While the vertical intergovernmental structures have been coordinated through the national government, Counties through the CoG have equally established their own horizontal frameworks for engagement. All Counties have established Emergency Operation Committees co-chaired by Governors and County Commissioners (a representative of the National Government at County level) to enable effective coordination of County response.

The CoG similarly developed a model regulation to necessitate the establishment of a County Emergency Fund, to be adopted by county governments and facilitate mobilization of resources toward COVID-19 mitigation. The fund consists of all monies donated toward COVID-19 emergency response at the county level. As of 29 April 2020, all the counties had committed a percentage of their resources.

\subsubsection{Procurement of COVID-19 supplies and fiscal transfers' conflict}

Public procurement processes during this pandemic have come with their own complexities. County governments through legislation are required to procure medical supplies from the State-Owned Agency for economies of scale and effective regulation and standard control. There have been numerous calls for transparency in the procurement of COVID-19-related supplies without much success. Allegations of corruption through overpriced supplies are rampant, and concerned officers have appeared before parliamentary committees (Presidency 2018). Claims of high-level misappropriation of COVID-19 funds have been rife.

Remarkably, while there have been strengthened intergovernmental relations between the two levels of government in terms of coordination of processes and communication during the period, the greatest missing link has been resourcing of county governments.

As at the end of the 2019/2020 fiscal year in June, county governments had not received 9.4 percent worth of their equitable share of allocation which is in complete violation of the Constitution, and the Statutory Cash Disbursement Schedule approved by parliament (National Treasury 2020d). This amount was in addition to an extra allocation to the Counties as part of COVID-19 pandemic emergency response measures. Complexity in funding for the counties further arose out of the Senate's inability to pass the basis for revenue sharing among county governments. The Senate had a protracted dispute that eventually was brokered by the president and opposition leader. By the time the Senate approved the basis, it was two months into the new fiscal year (National Treasury 2020a). In October, three months into the new fiscal year, 50 percent of the expected quarterly allocation was disbursed. It is clear that delayed disbursement to county governments will muddle county capacity to address the pandemic adequately.

Notwithstanding the absence of intergovernmental transfers, the CoG has made significant strides toward the support of the most vulnerable in select counties through partnership with development partners. As of 15 October 2020, some of the notable 
efforts to mitigate the pandemic include: establishment of active quarantine facilities and testing in 34 counties; 43 counties have trained and sensitized 4,860 health care workers and 8,602 community health volunteers; implementation of home-based care in 34 counties for a total of 6,665 persons under the care in the month of September have recovered from the virus (Council of Governors 2020c). The development partners key support through the CoG included: Provision of dignity hygiene products for women in the reproductive age within quarantine/isolation facilities; supported six tele-counsellors for manning hotlines in three counties, and strengthened and enhance women, youth, and PWD participation and influence in COVID-19 response coordination at the County level. Of greater importance is the development of the COVID-19 County Socio-Economic Re-Engineering and Recovery Strategy (CCSERS). The strategy is expected to guide County Governments to jump-start their economies through targeted planning and budgeting for steady growth (Council of Governors 2020a). We believe that the CCSERS will provide a link with the national government through its entities hence strengthening the already visible intergovernmental relations. CCSERS offers an opportunity to assess the cross-sectoral relations beyond the health function which has been occasioned by the pandemic. While we might not draw a conclusion of the sustainability of the current strengthened intergovernmental relations between the two levels of governments, we believe that enhanced intergovernmental relations enables greater governments' outputs.

We note that both levels of government have the realization that efficient and timely testing is a vital prerequisite for early identification and reporting. This coupled with adequate contact tracing, isolation and quarantine of contacts are critical prevention measures in slowing down the spread of the pandemic. Mass testing has however not been implemented due to high costs involved, inadequate technology, and expertise required to conduct the tests. As of June 2020, the government reported that there were 25 laboratories readily available in the country with capacity to conduct the tests.

As of 18 October 2020, the Ministry of Health reported cumulated tests numbers at 621,976 . It is our view that, with that level of testing, the national government can only gain traction in testing if county governments are capacitated and effectively resourced to assist in the process.

We have observed that COVID-19 has exposed weaknesses in the healthcare system that must be addressed going forward. Kenya's health system is made up of several systems notably, private, public, and faith based. The Public system is further divided into County and national government facilities. This calls for effective coordination between the two levels of government. These systems manifest a mismatch between available care and needs especially in critical specialist care. Kenya has only 537 intensive care beds and 265 ventilators to a population of 49 million. Further due to the pandemic routine activities have reduced such as antenatal care, deliveries, and immunization programs whose detrimental effects will be felt much later. The cost of managing COVID-19 is beyond the reach of average Kenyans who are economically poor and uninsured.

\subsection{Conclusion}

In conclusion, although no one yet knows the future for COVID-19, most experts agree that it is not going away anytime soon. COVID-19 crisis management has 


\section{Rose B. Osoro}

shown in some cases intergovernmental relations stood firm. Instances where there was national government obstruction, counties have innately responded horizontally by coming together and proactively standing up as governments. The role of each level of government therefore cannot be underscored. Intergovernmental relations both vertical and horizontal are of great consequence going forward. A collaborative and consultative environment between the two levels of government and among the 47 county governments is thus paramount.

\section{Bibliography}

Constitution of Kenya, 2010. Constitution of Kenya. Kenya Law. Available from: http://www. kenyalaw.org:8181/exist/kenyalex/actview.xql?actid=Const 2010

Council of Governors, K., 2020a. County COVID-19 Social Economic Re-Engineering Recovery Strategy, 2020/21-2022/23. Available from: https://cog.go.ke/component/k2/ item/211-county-covid-19-re-engineering-and-recovery-strategy-2020-21-2022-23

Council of Governors, K., 2020b. Statement on Preparedness of County Governments on COVID-19. Available from: https://www.cog.go.ke/cog-reports/category/109-covid-19; file://C:/Users/user/Downloads/Press \%20 statement \% 20 on \% 20preparedness $\% 20$ of $\% 20$ County $\% 20$ Governments $\% 20$ on $\% 20$ COVID-19\%20-\%203rd $\% 20$ September $\%$ 202020.pdf

Council of Governors, K., 2020c. Statement on COVID-19 Mitigation. Council of Governors. Available from: https://www.cog.go.ke/media-multimedia/statements/category/109covid-19?download=434:press-statement-on-preparedness-of-county-governments-oncovid-19-15th-october-2020-2020

Fielder, J., 2020. COVID-19 in Africa: Ground-Level View from a Clinician in Kenya-Why Are Cases Lower in Africa. MedPage Today. Available from: https://www.medpagetoday. com/infectiousdisease/covid19/89246

Judiciary, K., 2020. Milimani Law Courts Operations during COVID-19 Pandemic. Judiciary. Available from: https://www.judiciary.go.ke/download/public-notice-milimani-lawcourts-operations-during-covid-19-pandemic/

Kangu, J.M., 2015. Constitutional Law of Kenya on Devolution. Nairobi: Strathmore University Press. Available from: https://press.strathmore.edu/uploads/journals/strathmorelaw-journal/2SLJ1/2SLJ1_13Ke-Const-law-on-devolution-Kangu-TKabau.pdf

Kenya, G.o., 2012a. County Government Act. Kenya Law. Available from: http://www. parliament.go.ke/sites/default/files/2017-05/CountyGovernmentsAct_No17of2012_1.pdf

Kenya, G.o., 2012b. Public Finance Management Act. Kenya Law. Available from: http://kenyalaw.org:8181/exist/kenyalex/actview.xql?actid=No.\%2018\%20of\%202012

Kenya, G.o., 2020c. Intergovernmental Relations Act. Kenya Law. Available from: http:// kenyalaw.org:8181/exist/kenyalex/actview.xql?actid=No.\%202\%20of\%202012

Kenyan National Bureau of Statistics (KNBS), 2019. Kenya Population and Housing Census (KPHC). Available from: https://www.knbs.or.ke/?wpdmpro=2019-kenya-population-andhousing-census-volume-i-population-by-county-and-sub-county

Ministry of Heath, 2020. Ministry of Health Press Releases. Nairobi. Available from: https:// www.health.go.ke/press-releases/

Mininstry of Health Kenya, 2020. Targeted Testing Strategy for Corona Virus Disease 2019 (COVID-19) in Kenya. Nairobi. Available from: https://www.health.go.ke/wp-content/ uploads/2020/07/Targeted-Testing-Strategy-for-COVID-19-in-Kenya.pdf

National Treasury, K., 2020a. County Governments Cash Disbursement Schedule for FY 2020-21. National Treasury. Available from: http://www.parliament.go.ke/sites/default/ files/2021-08/schedule $\% 20$ of $\% 20$ cash $\% 20$ disbursements $\% 20$ to $\% 20$ counties $\% 20$ FY\% 202021-2022.pdf 
National Treasury, K., 2020b. Draft 2020 Budget Review and Outlook Paper. National Treasury. Available from: - http://ntnt.treasury.go.ke/wp-content/uploads/2020/11/PressRelease-on_Draft-2020-BROP.pdf

National Treasury, K., 2020c. Explanatory Memorandum for the Public Finance Management COVID-19 Emergency Response Fund Regulations, 2020. National Treasury. Available from: http://ntnt.treasury.go.ke/wp-content/uploads/2020/11/PFM-COVID-19Regulations-2020-Final-Regulations.pdf

National Treasury, K., 2020d. Public Statement on the Status of Payments to County Governments'. National Treasury. Available from: https://www.treasury.go.ke/media-centre/ general-press-releases.html?download=1150:public-statement-on-the-status-of-paymentsto-county-governments

Nordling, L., 2020. Africa's Pandemic Puzzle: Why So Few Cases and Deaths. Science, 369 (6505), 756-757.

Presidency, K., 2018. Executive Order No.2 of 2018 on the Procurement of Public Goods, Works and Services by Public Entities. Presidency. Available from: https://www.president. go.ke/2018/06/13/executive-order-on-procurement-of-public-goods-works-and-services-bypublic-entities/

Presidency, K., 2020a. 7th Presidential Address on the Corona Virus Pandemic: 8 Point Economic Stimulus Programme. Available from: https://www.president.go.ke/2020/05/23/ the-seventh-presidential-address-on-the-coronavirus-pandemic-the-8-point-economicstimulus-programme-saturday-23rd-may-2020/

Presidency, K., 2020b. National Emergency Response Committee Review Report. Presidency. Available from: https://www.president.go.ke/2020/03/12/17428/

Presidency, K., 2020c. Presidential Address on the State's Interventions to Cushion Kenyans agaisnt Economic Effects of Covid-19 Pandemic. Presidency. Available from: https://www. president.go.ke/2020/03/25/presidential-address-on-the-state-interventions-to-cushionkenyans-against-economic-effects-of-covid-19-pandemic-on-25th-march-2020/

Statistics (KNBS), K.N., 2020a. Quarterly Labour Force Report. Nairobi: Kenya National Bureau of Statistics (KNBS). Available from: https://www.knbs.or.ke/?page_id=3142

Statistics (KNBS), K.N., 2020b. Survey on Socio Economic Impact of COVID-19 on Households Report. Kenya National of Statistics (KNBS). Available from: http://dc.sourceafrica. net/documents/119956-COVID-19-Survey-Key-Indicators-Report.html

World Bank. 2016. Kenya Urbanization Review. World Bank, Washington, DC. (C) World Bank. https://openknowledge.worldbank.org/handle/10986/23753 License: CC BY 3.0 IGO. 